\title{
Perspektif Ibu Bapa Terhadap Permasalahan dan Cabaran dalam Pembentukan Nilai Murni Pelajar
}

\author{
Mohamad Khairi Haji Othman*, Mohd Zailani Mohd Yusoff, Fauziah Abdul Rahim, Alis Puteh, Muhamad Dzahir Kasa, NurFasihah Roslan \\ Pusat Pengajian Pendidikan dan Bahasa Moden, Universiti Utara Malaysia, 06010 Sintok, Kedah, Malaysia \\ *Corresponding author: m_khairi@uum.edu.my
}

\begin{abstract}
This study aims to examine parents' perspective towards issues and challenges in developing good values among secondary school students. This descriptive-survey study was conducted on a few respondents comprised of parents, through interviews, in one the states in Malaysia. This study found that the issue faced by parents is related to family relationship factors such as limited time spent with children, preference of children to share problems or stories with other people, parents' attitudes and children's own attitudes. Meanwhile, challenges faced by parents are children's peer influence and excessive use of technology. In conclusion, issues and challenges presented in this study are significant and should be made aware so that children can be molded at early stages to become future successors. Parenting skill is vital to ensure peace and harmony in the family. Good tutelage and support should be provided to the children according to their age so that there will be positive reception and feedback.
\end{abstract}

Keywords: Issues; challenges; development; positive values.

\begin{abstract}
Abstrak
Tujuan penyelidikan ini dijalankan adalah untuk meninjau perspektif ibu bapa terhadap permasalahan dan cabaran dalam membentuk nilai murni pelajar sekolah menengah. Kajian ini telah dijalankan di salah sebuah negeri yang terdapat di Semenanjung Malaysia. Kaedah kajian tinjauan deskriptif secara kualitatif telah dijalankan ke atas beberapa orang responden temubual yang terdiri daripada ibu bapa. Kajian mendapati masalah yang dihadapi oleh ibu bapa ialah terdiri daripada faktor hubungan kekeluargaan, peluang bersama anak yang terhad, anak-anak lebih selesa berkongsi dengan orang lain, sikap ibu bapa dan sikap anak-anak itu sendiri. Manakala cabaran yang dihadapi oleh ibu bapa pula ialah pengaruh rakan sebaya dan penggunaan teknologi. Kesimpulannya, masalah dan cabaran yang telah dikemukakan dalam kajian ini amat penting diketahui agar anak-anak dapat dibentuk dari awal supaya menjadi penerus bangsa yang berjaya. Ilmu keibubapaan adalah penting untuk membawa kebahagiaan dan keharmonian dalam keluarga masing-masing. Pendidikan dan asuhan yang baik perlu diberikan kepada anak-anak mengikut kesesuaian peringkat umur agar mendapat penerimaan dan maklum balas yang positif.
\end{abstract}

KataKunci: Permasalahan; cabaran; pembentukan; nilai murni

(C) 2016 Penerbit UTM Press. All rights reserved

\subsection{PENDAHULUAN}

Dasawarsa ini, negara kita seringkali dikaitkan dengan gejala sosial yang kian meruncing. Pelbagai kes jenayah yang telah berlaku dari sehari ke sehari sehingga mendatangkan mudarat kepada masyarakat sekeliling. Kebanyakan kes jenayah yang berlaku adalah melibatkan golongan remaja terutamanya pelajar sekolah. Azizi dan Rosnah (2007) menyatakan bahawa individu yang melanggar norma masyarakat setempat dikenali sebagai golongan yang bertingkah laku devian. Menurutnya lagi, golongan ini akan digelar sebagai delinkuen disebabkan mereka masih bersekolah.

Dapatan melalui akhbar Harian Metro pada 29 Disember 2010 menyatakan bahawa hampir tiga peratus daripada lebih lima juta pelajar dari 10, 000 sekolah rendah dan menengah terlibat dalam kes salah laku disiplin. Menurut Timbalan Menteri Pelajaran, Datuk Dr Wee Kah Siong menyatakan bahawa mengikut rekod kementerian 111,484 pelajar atau 72,557 pelajar sekolah menengah dan 38,927 murid sekolah rendah dikesan terbabit pelbagai salah laku disiplin pada tahun 2010. Antara kes salah laku disiplin termasuk kes jenayah (17,595 kes), ponteng sekolah (19,545 kes), berlaku kurang sopan (18,346 kes), kekemasan diri (21,384 kes), tidak mementingkan masa (17,808 kes), kelucahan (3,031 kes), vandalisme (5,212 kes) dan kenakalan (8,563 kes). Akhbar Kosmo 1 Julai 2012 menyatakan tentang dapatan kajian sebanyak 108, 650 daripada 5.3 juta pelajar sekolah rendah dan menengah di seluruh negara terlibat dengan kes salah laku. Menurut Tan Sri Muhyiddin Yassin, penyumbang utama kes salah laku pelajar ialah ponteng sekolah iaitu seramai 18, 550 pelajar.

Berdasarkan statistik di atas, kes salah laku yang berlaku adalah bersangkutan dengan kegagalan dalam menerapkan nilai-nilai murni dalam kalangan remaja terutamanya pelajar sekolah. Oleh itu, penekanan kepada persoalan nilai-nilai murni dalam sistem pendidikan Malaysia perlu diberi perhatian yang serius. Pelaksanaan Kurikulum Baru Sekolah (KBSR) dan Kurikulum Bersepadu Sekolah Menengah (KBSM) menggalakkan guru melaksanakan pendekatan penerapan nilai merentas kurikulum. 
Fatimi Hanafi dan Mohd Zamani Ismai (2006) menyatakan bahawa ketiadaan penghayatan nilai-nilai murni dalam masyarakat menyebabkan kelakuan mereka terarah kepada perlakuan negatif dan cenderung untuk berlakunya keruntuhan akhlak akibat daripada penghayatan akhlak yang lemah (Harery Abu Saad, 2007). Justeru, pelbagai masalah dan cabaran yang dihadapi oleh banyak pihak dalam membentuk nilai murni dalam kalangan remaja khususnya insan yang bergelar pelajar.

\subsection{PENYATAAN MASALAH}

Golongan pelajar sekolah menengah adalah dalam lingkungan umur 13 sehingga 19 tahun yang mana kumpulan ini berada dalam fasa remaja. Terdapat pelbagai perubahan yang berlaku ke atas diri remaja dari aspek fizikal, sosial, mental dan emosi. Perubahan ketara dapat dilihat dari segi fizikal dan pemikiran mereka yang mana berlakunya pertumbuhan pada otot-otot, alat kelamin dan organ-organ lain, manakala dari sudut pemikiran menjadi lebih matang dan berkonsep menyeluruh.

Remaja bukan sahaja sebagai aset kekayaan semula jadi negara, bahkan mempunyai peranan utama dalam meresapkan aura baharu dalam dunia politik, ekonomi dan hal ehwal kemasyarakatan negara. Remaja merupakan aset negara yang mampu melakukan perubahan yang boleh mengembalikan imej negara di mata dunia. Gejala sosial pada masa ini semakin menular dan telah menjadi kanser dalam jiwa insan yang bergelar remaja. Hal ini demikian kerana masalah ini sudah sukar untuk dibendung sekiranya golongan ini dibiarkan begitu sahaja.

Pelbagai faktor penyebab utama yang membawa remaja kepada jalan songsang tersebut. Antaranya ialah faktor diri remaja itu sendiri, latar belakang keluarga, gaya asuhan ibu bapa dan juga pihak sekolah. Secara umumnya, institusi pendidikan khususnya sekolah mempunyai peranan yang besar dalam menerapkan nilai-nilai murni dalam kalangan pelajar. Melaluinya, pelajar akan dididik supaya bermoral, berakhlak dan mengamalkan budaya yang murni. Pendidikan dan sistem persekolahan harus memainkan peranan yang berkesan dalam menyemai nilai-nilai murni sebagai langkah membentuk modal insan (Abd. Rahim Abd Rashid, 2001).

Institusi kekeluargaan terutamanya melihat kepada cara didikan dan perapatan ibu bapa dengan anak-anak yang pada era ini kian menampakkan jurang yang ketara. Pada masa ini, kebanyakan hubungan antara ibu bapa dengan anak-anak hanya melalui gajet sematamata. Tanpa penguasaan penjaga, remaja boleh bertindak di luar batasan dan terlibat dengan gejala sosial. Perkara ini terjadi dengan kemungkinan bahawa terdapat masalah dan cabaran tertentu dalam membentuk nilai-nilai murni dalam diri remaja tersebut. Kesalahan tidak harus ditunding kepada sesetengah pihak kerana berkemungkinan juga disebabkan oleh semua pihak. Sejurus dengan itu, penyelidik merasakan perlu melaksanakan kajian tentang permasalahan dan cabaran dalam pembentukan nilai murni pelajar sekolah terutama daripada perspektif ibu bapa.

\subsection{OBJEKTIF KAJIAN}

Objektif kajian ini boleh diringkaskan seperti berikut.

1. Mengenal pasti masalah yang wujud dalam membentuk nilai murni dalam kalangan pelajar.

2. Mengenal pasti bentuk cabaran yang perlu ditempuhi semasa membentuk nilai murni dalam kalangan pelajar

\subsection{METODOLOGI}

Kajian ini berbentuk tinjauan deskriptif dengan menggunakan kaedah kualitatif. Responden kajian ini adalah terdiri daripada beberapa orang ibu bapa pelajar tingkatan empat dan dua di sebuah sekolah menengah harian di daerah Kuala Muda/Yan, Kedah yang telah dipilih secara rawak mudah untuk sesi temu bual. Instrumen kajian semi struktur protokol ialah temu bual. Soalan-soalan protokol temu bual ini dibina dan diubah suai dengan merujuk beberapa kajian lepas. Data dari temu bual separa berstruktur tentang aspek yang dikaji dirakam telah ditranskripsi. Seterusnya dianalisis dengan mengenal pasti tema-tema utama yang timbul dari hasil temu bual dan dikategorikan mengikut pembahagian asal kategori dalam soalan protokol temubual.

\subsection{DAPATAN KAJIAN}

\section{Masalah yang Dihadapi oleh Ibu Bapa dalam Pembentukan Nilai Pelajar}

Pembentukan nilai-nilai murni bukan merupakan sesuatu perkara yang sukar untuk diterapkan, bahkan bukan juga suatu perkara yang mudah dalam diri anak-anak. Hal ini demikian kerana terdapat masalahnya yang tersendiri untuk membentuk nilai-nilai murni dalam diri mereka. Dapatan kajian mendapati terdapat beberapa masalah yang telah ditimbulkan oleh responden kajian mengenai pembentukan nilai-nilai murni dalam diri anak-anak.

Masalah pertama yang telah dikemukakan ialah tentang faktor hubungan kekeluargaan yang wujud antara ibu bapa dengan anak-anak. Responden menyatakan bahawa hubungan yang jauh antara ibu bapa dengan anak-anak akan menyebabkan kesukaran dalam membentuk nilai murni kepada anakanak. Ibu bapa yang tidak mampu untuk berkomunikasi dan berinteraksi dengan baik bersama anak-anak akan menyebabkan anak-anak tidak membina hubungan yang mesra dengan mereka. Hal ini dapat dijelaskan melalui kenyataan berikut:

.....Silap saya. Saya terlampau garang dengan anak-anak, tu sebab mereka takut nak dekat dan borak dengan saya. Sampai sekarang bila semиa dah besar, mereka masih duduk jauh-jauh dengan saya. Sedih jugak kadang-kadang tu. Nak ajak, nak belai, saya pun dah tua. Segan tu ada, sama jugak dengan ego. Kesan yang paling saya nampak ialah mereka hormat saya, tapi tidak mesra la....

(int. Pak Cik Lan/ 22.3.2015) 
Tambah responden lagi, akibat daripada bekerja secara maksimum menyebabkan tiada ruang dan peluang untuk bersama anak-anak bahkan keluarga. Hubungan dengan anak-anak hanya dilihat kepada status darah daging, bukan kepada kemesraan yang seharusnya ditunjukkan oleh ibu bapa. Anak-anak akan menjarakkan diri mereka apabila ibu bapa gagal dalam memberikan perhatian yang secukupnya. Ini boleh dibuktikan dengan kenyataan berikut:

.....Saya keluar keje pukul 6.30 pagi. Masa tu anak-anak dalam bilik air lagi. Saya balik pukul 7.00 malam. Bila sampai rumah, penat dah. Tak sempat dah nak berborak dengan anak-anak. Memang jarang berkumpul sekeluarga. Kadangkadang risau jugak, takut memberontak dan tertekan.

(int. Kak Dah/23.4.2015)

....Terlampau jaga atau terlampau buat tak tahu pon jadi masalah anak-anak ni. Memang cara dia, takleh terlalu dikawal dan diberi kebebasan. Kalau dibiarkan mereka akan bertindak di luar jangkaan kita....

(int. Kak Mila/23.4.2015)

Pembentukan nilai-nilai murni amat perlu untuk mewujudkan modal insan yang mempunyai akhlak yang baik. Hal ini menjadikan hubungan kekeluargaan menjadi faktor utama dalam membantu anak-anak berkembang menjadi manusia yang berakhlak mulia. Namun begitu aspek ini menjadi salah satu masalah dalam membentuk nilai diri anak-anak.

Selain daripada itu, responden turut menyatakan bahawa selain daripada masalah hubungan kekeluargaan, masalah yang seterusnya ialah peluang bersama anak-anak yang terhad. Hal ini bermakna anak-anak tidak mempunyai peluang yang banyak untuk bercerita mahupun meluangkan masa dengan ibu bapa. Peluang untuk mendengar dan memahami sesuatu perkara yang ingin disampaikan oleh anak-anak sepatutnya perlu diberikan kepada diri ibu bapa sama ada perkara tersebut hanya menyentuh hal peribadi ataupun sekolah. Keterbatasan ini akan menjadikan individu tesebut kurang yakin diri dan tidak peka dengan keadaan sekeliling. Kenyataan berikut sebagai menjelaskan lagi tentang perkara di atas:

.....Saya keje banyak. Tak sempat la nak dengar semua cerita anak-anak. Ada jugak sampai merajuk dengan saya sebab saya buat tak tahu je kat dia masa dia cerita....

(int. Kak Dah/23.4.2015)

....Macam saya bagitahu tadi la. Saya ni terlampau tegas ngan anak-anak. Jadi, anak-anak terbatas nak cite ngan saya. Saya cuba nak tunjuk yang saya ni 'care' dengan diorang, tapi diorang tak perasan...

(int. Pak Cik Lan/22.4.2015)

Hal ini telah diketahui oleh ibu bapa akan kesannya kepada jiwa anak-anak, namun akan cuba diatasi supaya peluang untuk anak-anak bersama dengan ibu bapa wujud bagi menjamin kesejahteraan anak-anak. Perkongsian amat diperlukan dalam sesebuah keluarga yang mana boleh menjamin ketelusan dan kepercayaan antara ahli keluarga, bahkan mampu membina ukhuwah yang erat antara mereka. Segala perkara yang perlu atau tidak, akan dikongsi bersama antara mereka. Keterbatasan dalam berkomunikasi sehingga meminimumkan percakapan boleh menjadi satu masalah dalam membentuk nilai diri anakanak.

Responden turut berpendapat bahawa rutin harian sekolah anak-anak kadang-kadang mengehadkan mereka daripada berbual dan berkongsi sesuatu dalam tempoh yang lama. Hal ini demikian kerana, jadual harian anak-anak sangat padat dengan program atau aktiviti yang perlu disertai seperti kelas Fardu-Ain, Kelas Al-Quran secara privasi, kelas tambahan dan waktu menyiapkan kerja sekolah. Menurut responden:

\begin{abstract}
....Purata masa anak akak ada kat umah ialah 1/4 je. Balik umah semata-mata nak rehat dan tidur. Jadual terlalu padat sampai akak kadang-kadang naik kesian tengok dia. Komunikasi akak dengan dia terbatas sikit la. Susah nak tahu apa yang berlaky sehari-hari dalam kehidupan dia. Sebab nilah, rutin harian yang terlalu padat.
\end{abstract}

(int. Kak Mila/23.4.2015)

Keluarga merupakan tempat atau destinasi utama dalam kehidupan seseorang. Namun begitu bagi segelintir anak-anak, mereka lebih mengutamakan rakanrakan berbanding keluarga sendiri. Masalah seterusnya dalam membentuk nilai-nilai murni diri pelajar ialah anak-anak lebih selesa bersama rakan-rakan berbanding bersama keluarga. Hal ini terbukti apabila responden memberikan kenyataan berikut:

.....Kalau akak suruh beli barang kat kedai, ada je alasan. Malu la, penat la. Tapi kalau bab kawan, dia memang laju. Kawan nak datang umah ni, rela dikemaskan dua hingga tiga hari sebelum kawan datang....

(int. Kak Mila/23.4.2015)

Keselesaan ini berkemungkinan disebabkan beberapa alasan yang mana rakan merupakan individu yang sama umur dengan anak-anak. Hal ini menyebabkan mereka selesa untuk bersama rakan dan berkongsi semua perkara. Selain itu, masalah ini juga terjadi disebabkan oleh sikap ketidakterbukaan ibu bapa terhadap anak-anak mereka. Ini boleh dibuktikan dengan kenyataan berikut:

....Akak pernah tengok la, ada sorang budak pompuan ni selalu je kena marah dengan mak dia. Buat keja pon kena marah, tak buat lagi lah. Anak ni nak la jugak bercerita kan, tapi mak dia 'cut' cepat-cepat dengan bagi arahan lain kepada anak. Mak dia selalu pikir negatif kat anak tu, walhal akak tengok anak dia okay je...

(int. Kak Dah/23.4.2015)

Di samping itu, dalam membincangkan tentang masalah ini, responden berpendapat bahawa anak-anak tidak digalakkan untuk berkongsi dengan orang lain selain daripada ibu bapa. Hal ini kerana bimbang sekiranya orang lain mengambil kesempatan ke atas kelemahan diri anak-anak. Ini dapat dinyatakan seperti berikut:

.....Bagi saya aliran pemikiran orang yang lebih dewasa dengan aliran pemikiran orang muda berbeza. Kami memandang sesuatu perkara dari sudut yang berbeza, manakala orang muda turut memandang sesuatu perkara dari sudut yang berbeza juga....

(int. Pak Cik Lan/22.3.2015) 
Responden turut memberikan contoh isu mengenai kebenaran penggunaan telefon, jika tidak dibenarkan penggunaan telefon kepada anak-anak, akan dianggap ibu bapa tidak menyayangi mereka walhal ibu bapa risau akan keberangkalian yang negatif bakal berlaku ke atas diri mereka. Setiap ibu bapa pasti akan membimbangi akan perkembangan diri anak-anak mereka sama ada membentuk dengan akhlak yang baik atau sebaliknya. Hal ini demikian kerana, sekiranya anak-anak bergaul dengan kumpulan rakan yang baik, sedikit-sebanyak boleh menenangkan hati seorang ibu. Namun sekira disebaliknya boleh menyebabkan wujudnya kerisauan dalam diri mereka. Responden membuat keluhan seperti berikut:

.....Akak tak kisah anak-anak nak berkawan. Tapi kalau boleh pilih la kawan yang elok perangainya. Bukan apa, bila dah kongsi macam-macam ni, orang tahu kelemahan kita. Pengaruh kawan ni kuat. Kalau mak ayah suruh, belum tentu buat. Tapi kalau kawan suruh, belum ajak dah sampai....

(int. Kak Mila/23.4.2015)

Selain daripada tiga masalah membentuk nilai-nilai murni dalam diri pelajar, terdapat beberapa pandangan lain tentang masalah yang perlu dihadapi oleh ibu bapa . Responden berpendapat bahawa antara masalah lain yang dihadapi oleh mereka untuk membentuk nilai-nilai murni dalam diri anak-anak ialah sikap ibu bapa itu sendiri. Hal ini dijelaskan melalui kenyataan berikut:

.....Pada pendapat saya, kesukaran dalam membentuk nilai-nilai murni dalam kalangan anak-anak iaitu tiga orang yang terakhir ialah sifat saya yang kurang garang terhadap mereka pada peringkat awal. Memangla masalah ini bukan sebagai satu masalah yang besar, walaupun tidak garang, tetapi saya akan sentiasa memberi nasihat...

(int. Pak Cik Lan/22..3.2015)

Hal ini turut disokong oleh responden lain bahawa sikap ibu bapa memainkan peranan penting untuk membentuk nilai-nilai murni dalam diri anak-anak.

.....Saya ni dah la tak garang, tambah pula saya sering membiarkan anak-anak mendapat apa yang diinginkan dan kurang bertegas dengan mereka mungkin menjadi sebab anak-anak naik kepala....

(int. Kak Mila/23.3.2015)

....Zaman sekarang kan semua benda kat hujung jari. Takkan la akak tak bagi guna ipad atau telefon kat anak-anak. Nanti tersekat pulak perkembangan mereka. Ipad akak pun dah jadi hak dia sekarang. Biarkan je la asalkan tak jadi benda buruk....

(int. Kak Dah/23.3.2015)

Di samping itu, responden turut berpendapat bahawa tidak semua anak-anak mempunyai sikap yang sama dan mudah untuk dibentuk perangai antara mereka. Hal ini menjadi salah satu masalah yang perlu dihadapi oleh ibu bapa untuk membentuk nilai-nilai murni dalam diri anak-anak. Kebanyakan ibu bapa memerlukan sedikit masa untuk mengekori cara pembesaran dan tingkah laku anak-anak dengan melakukan sedikit pemerhatian terhadap anak-anak.

....Perangai setiap anak adalah berbeza, jadi, saya perlu mengikut cara masing-masing....

(int. Pak Cik Lan/22.3/2015)

Responden turut menyatakan dalam membentuk nilai-nilai murni kepada anak lelaki agak mencabar berbanding anak perempuan. Hal ini demikian kerana jiwa anak lelaki agak berlainan dengan jiwa anak perempuan yang mana anak lelaki lebih berjiwa keras. Komitmen seorang isteri di samping pekerjaan sebagai seorang guru memberi penangan yang hebat kepada responden dalam membesarkan dan mendidik anak lelaki kerana pendekatan yang perlu digunakan oleh responden dalam bentuk perapatan, bukannya pendekatan paksaan atau bentuk yang agresif. Menurutnya:

....Anak lelaki ni berbeza dari segi pendekatannya. Saya kena banyak betolak ansur dengannya dan banyak mendengar apa yang ingin disampaikan kepada saya. Kekerasan tidak sesuai dengannya, nanti semakin memberontak. Jadi saya perlu menggunakan cara halus iaitu dengan memujuk, menunjukkan sesuatu perbuatan secara praktikal dan memberi nasihat kepadanya. Baharulah dia akan fokus dengan apa yang saya ingin sampaikan kepadanya...

(int. Kak Mila/23.3.2015)

Hal ini turut diperkatan tidak semua anak boleh menggunakan cara agresif dan sekadar nasihat sahaja kerana di antara mereka perlu diberi peringatan seperti amaran dan rotan.

...Saya akan melihat kepada pembentukan diri mereka melalui pemerhatian seterusnya baharulah saya menentukan jenis pendekatan yang sesuai. Saya tidak mempunyai masalah yang begitu ketara dalam membentuk nilai-nilai murni dalam diri anak-anak. Hal ini demikian kerana sejak mereka kecil saya telah mendidik dan menerapkan nilai-nilai murni dalam diri mereka seperti bertanggungjawab, rajin, menghormati dan jujur. Contohnya, anak sulung saya ketika berusia 5 tahun telah boleh mengemas rumah, menjaga adik dan boleh mengemas diri sendiri dengan baik. Bukan apa, saya tidak mahu anakanak menjadi seperti saya semasa zaman kecil dahulu yang mana tidak pandai untuk melakukan sebarang pekerjaan...

(int. Kak Dah/23.3.2015)

Secara jelasnya, anak-anak memang perlu menggunakan pendekatan yang berbeza dalam membentuk nilai-nilai murni dalam diri mereka. Hal ini bagi memastikan usaha saya mendatangkan hasil yang baik, bahkan saya dapat menjamin keberlangsungan kehidupan anak-anak saya dengan baik serta terurus. Penggunaan pendekatan yang berbeza boleh diaplikasikan mengikut jiwa semula jadi anak-anak. Sekiranya ada anak yang sensitif, maka tidak boleh menggunakan pendekatan yang agresif, pendekatan sindiran tidak boleh digunakan kepada anak yang tidak boleh disindir. Hal ini untuk memastikan penerimaan mereka akan penerapan dan pembentukan nilai yang ingin disampaikan oleh ibu bapa.

\section{Cabaran yang Dihadapi oleh Ibu Bapa dalam Pembentukan Nilai Pelajar.}

Dalam melaksanakan sesuatu tugasan akan wujudnya beberapa halangan atau cabarannya yang tersendiri. Hal ini menjadi salah satu syarat yang perlu dihadapi oleh ibu bapa untuk membentuk nilai-nilai murni dalam diri anak-anak. Terdapat beberapa cabaran yang perlu dihadapi oleh ibu bapa dan antara pendapat mereka ialah pengaruh rakan sebaya dan penggunaan teknologi. 
Persekitaran hidup kini yang kian mencabar menjadi satu cabaran kepada ibu bapa. Hal ini demikian kerana anak-anak terdedah dengan anasir-anasir negatif, pergaulan mereka mudah dipengaruhi oleh rakan-rakan yang mempunyai nilai yang tidak baik . Tambahnya lagi, selain ibu bapa, kawan menjadi tempat untuk anak-anak mengadu dan berkongsi segala perkara. Perkara ini menjadi kebimbangan kepada para ibu bapa terhadap pembentukan sikap dan keselamatan anak-anak mereka.

....Saya lebih suka kalau anak-anak meluahkan segala perkara kepada saya sebagai seorang bapa. Manusia sekarang tidak kenal kawan atau lawan. Bila-bila masa mereka boleh ambil kesempatan bila dah tahu kelemahan. Bahaya untuk anak-anak yang berada dalam pergaulan yang bersifat ekstrem pada masa ini. Bukan tidak percayakan anak-anak, tetapi perlu meletakkan keraguan ke atas mereka walaupun sedikit....

(int. Pak Cik Lan/22.3.2015)

....Saya tidak bimbang sekiranya saya kenal dengan siapa anak-anak saya bergaul, yang menjadi kerisauan adalah apabila anak-anak tidak mendedahkan dengan siapa mereka bergaul. Saya sentiasa bertanyakan kepada anak-anak tentang kawan-kawan mereka dan sentiasa memberi peluang kepada mereka untuk bercerita mengenai rutin harian mereka. Hati seorang ibu dapat mengenal pasti sama ada penceritaan yang disampaikan oleh anak-anak, tetapi setakat ini anak-anak tidak pernah menipu saya lagi. Sebab itulah pembentukan nilai-nilai murni dalam diri anak-anak saya telah terapkan sejak mereka kecil...

(int. Kak Mila/23.3.2015)

....Anak-anak saya ramai kawan. Ke hulu, ke hilir dengan kawan je memanjang. Antara saya dengan kawan dia, dia lebih rapat dengan kawan-kawan. Tu lah, adakalanya risau jugak dengan pergaulan budak-budak sekarang. Tak tahu apa yang dibualkan dan apa yang dibuat. Bukan macam akak dulu-dulu yang takde benda nak main. Tapi, In Shaa Allah akak percayakan anak-anak akak....

(int. Kak Dah/23.3.2015)

Dapatan kajian mendapati pengaruh rakan sebaya sebagai cabaran dalam membentuk nilai-nilai murni. Jika dilihat pada logiknya, pendapat responden adalah benar. Pengaruh rakan sebaya membawa aura atau karisma yang kuat kepada anak-anak kerana hampir sehari mereka bersama kecuali di rumah. Hal ini menyebabkan mereka lebih selesa dan mengenali rakan-rakan berbanding keluarga. Jika ditambah pula dengan keluarga yang porak-peranda, maka kecenderungan untuk anak-anak mengikut jejak rakan sebaya adalah tinggi.

Selain daripada pengaruh rakan sebaya dan persekitaran, responden turut berpendapat bahawa penggunaan teknologi juga menjadi salah satu cabaran kepadanya membentuk nilai-nilai murni dalam diri anak-anak.

....Penggunaan gajet seperti telefon hanya didedahkan kepada anak-anak setelah mereka tamat Sijil Pelajaran Malaysia. Akak dah bagitahu awal-awal sebab dan akibat penggunaan telefon kepada anak-anak supaya mereka faham dengan situasi yang akan jadi. Bukan apa, tak nak mereka salah faham dan memberotak dengan tindakan akak. Kini akak bersyukur, anak-anak tidak terlalu obses dengan telefon bimbit malah menggunakannya dengan bermanfaat”.

(int. Kak Mila/23.3.2015)

....Budak-budak sekarang, kalau kita tak bagi telefon pun, mereka pandai. Petang-petang habis sekolah, mereka pegi Cyber Café. Bukan kita tahu yang mereka nakkan sesuatu perkara yang selari dengan peredaran zaman. Bukan tak penting internet tu, tapi kalau boleh guna bila perlu je lah. Banyak benda yang tak elok dengan internet ni. Budak-budak ni, kalau kawan tengok, ikut tengokjugak tanpa tahu benda tu baik ke tak....

(int. Pak Cik Lan/22.3.2015)

....Akak ada jugak perhatikan mak bapak sekarang. Budak sebesar setahun tu dah bagi tab, mana la tak rosak budak tu. Sampai ketagih dibuatnya. Nak suruh budak tu duduk diam, hulur tab. Sampai besar memang duduk dengan benda tu la kot. Tu yang suruh masuh dapur pun tak nak. Buat kerja rumah malas...

(int.Kak Dah/23.3.2015)

Penggunaan teknologi yang terlampau obses ini bukan sahaja boleh merosakkan akhlak anak-anak, malah mengehadkan pergaulan mereka dengan masyarakat dan kurang mengaplikasikan nilai-nilai murni yang sedia ada. Jelaslah bahawa pendedahan penggunaan teknologi kepada anak-anak di usia muda boleh mengakibatkan wujudnya lompang pembentukan nilai-nilai murni.

Namun begitu ada juga responden yang mengatakan tidak mempunyai cabaran yang rumit dalam mengendalikan anak-anak supaya menerapkan nilai-nilai murni dalam diri mereka. Hal ini demikian kerana, responden telah menyerapkan nilai-nilai tersebut sejak anakanaknya masih kecil dan tidak hairanlah sekiranya anak-anak beliau tidak mempunyai salah laku yang tinggi.

....Saya amat bersyukur, kerana setakat ini anak-anak tidak memeningkan kepala saya. Mungkin juga disebabkan anak-anak saya kebanyakannya perempuan yang mana mereka ini mudah untuk dibentuk. Anakanak saya tiga dari atas mempunyai sikap yang baik yang mana mungkin saya amat bertegas dengan mereka semasa kecil...

(int. Pak Cik Lan/22.3.2015) 
Hal ini juga disokong oleh responden lain yang mana tidak mengalami kesukaran yang kritikal untuk membentuk nilai-nilai murni dalam diri anak-anak. Beliau telah membentuk nilai-nilai tersebut sejak anak-anaknya masih kecil dengan rasional apabila meningkat dewasa, anak-anak akan sendirinya membesar dengan penuh nilai murni. Tambahnya lagi:

\section{... Bila dah anak-anak ni besar, susah sikit nak bentuk nilai murni. Tidak semua remaja senang nak ikut apa yang kita tunjuk. Itulah sebab daripada mereka kecil kita kena ajar sikit-sikit...}

(int. Kak Mila/23.3.2015)

Cabaran seterusnya untuk membentuk nilai-nilai murni dalam diri anak-anak ialah harapan yang tinggi kepada anak-anak. Setiap ibu bapa menginginkan kejayaan daripada anak-anak lebih besar daripada kejayaan yang diperoleh ibu bapa pada masa ini. Hal ini menyebabkan mereka meletakkan harapan menggunung yang harus dicapai oleh anak-anak. Kenyataan responden adalah seperti berikut:

....Saya risau sekiranya anak-anak gagal dalam memenuhi harapan saya walaupun adakalanya saya terfikir bahawa akan ada kepincangan yang akan berlaku. Memang anak-anak saya semakin cerah masa depan mereka, cuma sebagai ibu yang berpendidikan, saya mempunyai harapan yang menggunung ke atas diri mereka...

(int.Kak Mila/23.3.2015)

Sambungnya lagi:

....Jika saya seorang guru, maka anak-anak perlu memiliki kerjaya yang lebih bagus berbanding saya. Saya telah mendidik mereka untuk menjadi seorang yang berguna serta berwawasan dan saya ingin melihat hasilnya kelak. Andai mereka tidak terdidik dengan baik dan gagal menunjukkan nilai-nilai yang sepatutnya, maka sedikit sebanyak akan terpalit di wajah saya sebagai seorang ibu....

(int.Kak Mila/23.3.2015)

Berdasarkan kenyataan di atas hanya seorang responden yang menyatakan bahawa cabarannya untuk membentuk nilai-nilai murni dalam diri anak-anak ialah harapan ibu bapa yang terlalu tinggi terhadap anak-anak. Secara ringkasnya dapatan kajian mendapati cabaran yang dihadapi oleh ibu bapa untuk membentuk nilai-nilai murni dalam diri anak-anak ialah pengaruh rakan sebaya dan penggunaan teknologi.

\subsection{PERBINCANGAN DAN RUMUSAN}

\section{Masalah yang Dihadapi Ibu Bapa Membentuk Nilai-Nilai Murni dalam Diri Pelajar}

Dalam melihat kepada masalah dan cabaran membentuk nilai-nilai murni dalam diri pelajar, penyelidik menjalankan kajian melalui soal selidik dan juga menemu bual beberapa orang responden untuk mendapatkan pandangan serta pendapat daripada mereka. Dapatan kajian mendapati bahawa faktor sikap ibu bapa, faktor hubungan kekeluargaan, peluang yang terhada bersama anak-anak, anak-anak yang lebih selesa dengan orang lain dan sikap anak-anak menjadi masalah kepada ibu bapa untuk membentuk nilai-nilai murni dalam diri pelajar.

Masalah yang dihadapi oleh para ibu bapa untuk membentuk nilai-nilai murni anak-anak pula ialah sikap ibu bapa itu sendiri. Hal ini demikian kerana terdapat antara mereka yang kurang tegas dan bersikap garang dengan anak-anak. Seterusnya menyebabkan anak-anak kurang menghormati dan mengasuh diri mereka dengan akhlak yang baik. Dapatan kajian ini disokong dengan kajian yang dibuat oleh Rohayati Derani (2004) menyatakan bahawa kegagalan ibu bapa dalam mendidik anak-anak akan menjejaskan masa depan mereka yang boleh mengakibatkan remaja terlibat dengan kegiatan yang tidak sihat, seterusnya tidak mampu untuk membentuk diri menjadi individu yang berguna dan berwawasan. Zakaria Stapa, Ahmad Munawar Ismail dan Noranizah Yusuf (2012) menyatakan bahawa ibu bapa memainkan peranan penting dalam mencorakkan pendidikan anak-anak dan membentuk asas-asas perlembangan diri seseorang anak. Tambahnya lagi, ibu bapa harus menunjukkan contoh sikap seperti ingin tahu dan suka bergaul kepada anak-anak bagi membimbing kelakuan mereka.

Selain daripada itu masalah seterusnya ialah sikap anak-anak itu sendiri yang berbeza dari segi cara pembesaran mereka yang mana ada di antara anak-anak boleh dibentuk dengan mudah dan ada yang sukar. Dapatan kajian ini disokong oleh kajian Suerlin Diah Utami (2013) yang menyatakan bahawa bagi dalam mendidik anak-anak, ibu bapa perlu memberikan contoh supaya dapat ditiru oleh anak-anak. Tambahnya lagi, hukuman terhadap anak-anak amat berpengaruh dengan tujuan untuk memberi peringatan kepada mereka agar tidak mengulanginya. Selain itu, sebaiknya ibu bapa perlu memberikan pengetahuan kepada mereka dengan cara yang baik mengikut kesesuaian usia supaya mereka memahami maksudnya. Sambungnya lagi, sebaiknya mendidik anak dengan kelembutan dan kasih sayang supaya lebih dekat dengan anak-anak serta mudah untuk memberikan pendidikan.

Dapatan kajian juga mendapati bahawa faktor hubungan kekeluargaan juga menjadi masalah dalam membentuk nilai-nilai murni diri pelajar. Hal ini demikian kerana, kemungkinan jurang yang wujud antara anak dengan ahli keluarga menjadi penyebab kepada salah laku anak-anak dan hal ini boleh mempengaruhi perkembangan peribadi anak-anak. Zhang et.al dalam Aziyah Abu Bakar, Wan Abd Aziz, Che Hasniza dan Yahya Mohamed Ariffin (2011) menyatakan bahawa bagi mengekalkan keharmonian dalam hubungan perseorangan, individu patut berkomunikasi dalam cara yang dapat membantu memelihara dan mengekalkan hubungan harmoni di samping mengelak daripada terjadinya konflik. Abd Razak Zakaria dan Norani Mohd Salleh (2011) menjelaskan bahawa komunikasi yang jelas antara ibu bapa dan anak didapati memberikan peluang untuk ibu bapa berinteraksi dengan baik untuk terlibat sama dalam pelajaran anak-anak. Tambahnya lagi, ibu bapa yang mengamalkan komunikasi dua hala memberikan runag kepada anak-anak untuk bermesra dan bertukartukar pandangan serta anak-anak boleh bertanyakan pendapat ibu bapa.

Selain itu, antara masalah lain yang terlibat ialah peluang bersama anak adalah terhad yang mana disebabkan oleh kesibukan ibu bapa dalam bekerja dan rutin harian anak-anak yang padat. Dapatan kajian selari dengan Mac Iver dalam kajian Zakiyah Jamaluddin dan Ismail 
Kiprawi (2004) menjelaskan bahawa hubungan antara ibu bapa dengan anak-anak sangat penting untuk mencetuskan perkembangan psikososial anak-anak yang sihat. Tambahnya lagi, tingkah laku delinkuens akan lebih mudah tercetus sekiranya remaja kekurangan kasih sayang daripada ibu bapa. Peluang dan ruang yang terhad akan mengehadkan interaksi anak-anak dalam keluarga. Hal ini menyebabkan anak-anak akan terbatas untuk berbincang dan berkongsi akan sesuatu perkara. Di samping itu, kajian ini juga menyatakan bahawa kesan daripada kasih sayang dan penjagaan daripada ibu bapa menyebabkan permbentukan tingkah laku delinkuens remaja dan ini akan mengakibatkan masalah dalam penyesuaian sosial apabila anak-anak semakin dewasa.

Masalah terakhir yang diperoleh daripada dapatan kajian ialah anak-anak lebih selesa berkongsi dengan orang lain berbanding keluarga. Peringkat umur yang sama dengannya menyebabkan mereka lebih selesa dan gembira bersama. Hal ini demikian kerana mereka dapat memahami jiwa masing-masing tanpa melihat kepada kebaikan atau keburukan sesuatu perkara. Kajian yang dibuat oleh Mazni Mustapha dan Mahiran Masdin (2014) menerangkan bahawa pengaruh rakan sebaya memberikan sokongan sosial kepada pelajar universiti, khususnya pelajar tahun pertama. Hal ini kerana, sokongan rakan sebaya mampu menyokong individu untuk menyesuaikan diri dengan persekitaran baru mampu bentuk sokongan ini mampu diperoleh daripada rakan sebaya ialah keselesaan fizikal dan emosional. Tambah kajian ini lagi, rakan sebaya lebih memahami dan mengetahui keperluan pembelajaran yang diperlukan oleh seseorang individu.

\section{Cabaran yang Dihadapi Ibu Bapa Membentuk Nilai-Nilai Murni dalam Diri Pelajar}

Dapatan kajian mendapati bahawa pengaruh rakan sebaya dan penggunaan teknologi menjadi cabaran kepada ibu bapa untuk membentuk nilai-nilai murni dalam diri pelajar. Hal ini selaras dengan kajian Hashim Bedu, Khairulhelmi Katip, Mohd Fahmi Mohd Sahid dan Syed Mohamed Syafeq Syed Mansor (2008) yang mana mengatakan bahawa antara punca berlakunya keruntuhan akhlak dalam kalangan remaja ialah pengaruh rakan sebaya. Kajian Azizi Yahaya, Noordin Yahaya, Juriah Bachok.(2010) mendapati bagi para pelajar, rakan sebaya sebagai tempat mereka mencurahkan masalah dan pengganti ibu bapa terutamanya bagi golongan yang mempunyai masalah di rumah. Tambahnya lagi, remaja biasanya akan memilih rakan sebaya yang mempunyai persamaan tingkah laku, sikap dan identiti mereka.

Antara faktor lain yang membawa pengaruh kepada cabaran kepada pembentukan nilai-nilai dalam diri pelajar yang dihadapi oleh ibu bapa ialah penggunaan teknologi yang kian berleluasa pada masa ini oleh golongan anak-anak. Dapatan kajian ini selari dengan kajian yang dibuat oleh Abdullah Sulong dan Mawaddah Abdullah (2010) yang menyatakan kewujudan pengaruh media massa seperti media cetak dan media elektronik dilihat sebagai punca yang menyebabkan akhlak belia pincang dan rosak. Tambahnya lagi, belia kini lebih berminat menonton televisyen, mendengar radio dan melayari internet berbanding bersemuka dengan ibu bapa serta ahli keluarga. Secara tidak langsung keasyikan ini menyebabkan pelajaran, kerja rutin harian dan tanggungjawab lain diabaikan. Selain daripada itu, masalah ini juga disokong oleh kajian Heru Winoto (2013) iaitu perkembangan media massa yang sepatutnya digunakan untuk mendapatkan bahanbahan yang ilmiah disalahgunakan oleh para belia dengan melihat kepada perkara-perkara yang berunsur negatif serta pornografi. Hal ini telah merosakkan moral penerus bangsa kita.

\subsection{PENUTUP}

Tuntasnya, terdapat lima masalah yang dihadapi oleh ibu bapa untuk membentuk nilai-nilai murni dalam diri anak-anak yang mana masalah tersebut terdiri daripada faktor hubungan kekeluargaan, peluang bersama anak yang terhad, anak-anak lebih selesa berkongsi dengan orang lain, sikap ibu bapa dan sikap anak-anak itu sendiri. Dari aspek cabaran terdapat dua cabaran utama iaitu pengaruh rakan sebaya dan pengaruh teknologi dalam membentuk nilai murni pelajar. Justeru, jika ibu bapa gagal dalam mendidik anak-anak akan menjejaskan masa depan mereka yang boleh mengakibatkan remaja terlibat dengan kegiatan yang tidak sihat, seterusnya tidak mampu untuk membentuk diri menjadi individu yang berguna dan berwawasan. Ibu bapa memainkan peranan penting dalam mencorakkan pendidikan anak-anak dan membentuk asas-asas perlembangan diri seseorang anak.

\section{Penghargaan}

Setinggi penghargaan kepada Geran RAGS KPT yang telah membiayai kajian ini dan artikel ini adalah sebahagian daripada hasil dapatan kajian.

\section{Rujukan}

Abd. Rahim Abd. Rashid. (2001). Nilai-Nilai Murni Dalam Pendidikan: Menghadapi Perubahan dan Cabaran Alaf Baru. Kuala Lumpur: Utusan Publications \& Distributors Sdn. Bhd.

Abd. Razak Zakaria \& Norani Mohd Salleh. (2011). Konteks Keluarga dan Hubungannya dengan Penglibatan Ibu Bapa dalam Pendidikan Anak-Anak di Sekolah Menengah. Jurnal Pendidikan Malaysia, 36 (1), 35-44

Abdullah Sulong \& Mawaddah Abdullah.(2010). Pengaruh Media Elektronik terhadap Keruntuhan Akhlak Pelajar. Skudai: Fakulti Pendidikan Universiti Teknologi Malaysia

Aziyah Abu Bakar, Wan Abd Aziz, Che Hasniza \& Yahya Mohamed Ariffin. (2011). Hubungan Komunikasi Keluarga dalam Menangani Keluarfa dalam Menangani Konflik dalam Kalangan Remaja. Jurnal Pengajian Media Malaysia, 13, 73-89

Azizi Yahaya \& Rosnah Buang. (2007). Punca Berlakunya Masalah Gejala Gengsterisme di Kalangan Remaja di Beberapa Buah Sekolah Menengah di Empat Buah Negeri. Fakulti Pendidikan Universiti Teknologi Malaysia.

Azizi Yahaya, Noordin Yahaya, Juriah Bachok.(2010). Perkaitan Antara Hubungan Kekeluargaan, Pengaruh Rakan Sebaya dan Kecerdasan Emosi Dengan Tingkah laku Delinkuen Sekolah Bestari Di Daerah Pontian. Melaka: Fakulti Pendidikan: Universiti Teknogi Mara.

Harery Abu Saad. (2007). Perkaitan Penghayatan Akhlak, Sikap Terhadap Sains, Pencapaian Dan Pemilihan Kerjaya Di Kalangan Pelajar Dalam Konteks Pembangunan Modal Insan Bersepadu Dalam Bidang Sains Dan Teknologi di SMKA. Tesis Doktor Falsafah Yang Tidak Diterbitkan. Universiti Kebangsaan Malaysia. 
Hashim Bedu, Khairulhelmi Katip, Mohd Fahmi Mohd Sahid \& Syed Mohamed Syafeq Syed Mansor. (2008). Keruntuhan Akhlak Dan Gejala Sosial Dalam Keluarga : Isu Dan Cabaran. Johor Bahru: Fakulti Pendidikan Universiti Teknologi Malaysia

Heru Winoto. (2013). Pengaruh Penyalahgunaan Penggunaan Teknologi Komunikasi Anak dan Remaja. Indonesia: Fakultas Ilmu Pendidikan Universitas Negeri Semarang.Malaysia.

Mazni Mustapha \& Mahiran Masdin. (2014). Pengaruh Perapatan Ibu, Bapa dan rakan Sebaya ke atas Adaptasi di Universiti dan Kepuasan Hidup dalam Kalangan Pelajar Tahun Pertama Fakulti Psikologi dan Pendidikan UMS. Sabah: Fakulti Psikologi dan Pendidikan Universiti Malaysia Sabah.

Mohd. Zamani Ismail \& Fatimi Hanafi. (2006). Penghayatan Nilai-Nilai Murni Dalam Masyarakat Berbilang Kaum di Malaysia. Prosiding Seminar Kebangsaan Pengajian Umum, 24-30. Skudai: Fakulti Pengurusan \& Pembangunan Sumber Manusia, Universiti Teknologi Malaysia.

Rohayati Derani. (2004). Persepsi Ibu Bapa terhadap Faktor-faktor Keruntuhan Akhlak Remaja Islam Masa Kini: Satu Tinjauan Di Taman Aman Anak Bukit, Alor Setar Kedah. Latihan Ilmiah Sarjana Muda. Universiti Teknologi Malaysia.

Suerlin Diah Utami. (2013). Peran Orang Tua Dalam Mendidik Anak. Indonesia: Fakultas Pendidikan Universitas Negeri Semarang.

Zakaria Stapa, Ahmad Munawar Ismail \& Noranizah Yusuf. (2012). Faktor persekitaran sosial dan hubungannya dengan pembentukan jati diri. Jurnal Hadhari Edisi Khas, 155-172.

Zakiyah Jamaluddin \& Ismail Kiprawi.(2004). Ikatan Dan Kawalan Ibu Bapa Terhadap Tingkah Laku Delinkuen. Sintok: Fakulti Pembangunan Sosial dan Manusia Universiti Utara 